\title{
ANALISIS PENGARUH PERSEPSI HARGA TERHADAP PERILAKU \\ PEMBELIAN PRODUK KEBUTUHAN SEHARI-HARI (STUDI PADA INDO \\ GROSIR JALAN MAGELANG)
}

\author{
Wirawan Seto Putro \\ Universitas Islam Indonesia
}

\begin{abstract}
This empirical research is intended to determine the relationship between consumer perceptions of the role of negative prices (Value Consciousness, Price Consciousness, Coupon Proneness, Sale Proneness, and Price Mavenism) with the role of positive prices (Price Quality Schema and Prestige Sensitivity). In this study the data were obtained through distributing questionnaires to 250 respondents, namely consumers who were making a purchase or those who had made a purchase at Indogrosir Jalan Magelang Yogyakarta. Based on the results of data analysis with SEM analysis with the AMOS program showed that there was an influence of negative variables. role price on positive role price, there is a negative role price influence on Value Consciousness in the role of negative prices, there is a negative role price influence on Price Mavenism on the role of negative prices, there is a negative influence role price on Price Consciousness on the role of negative prices, there is a negative role effect price on Sale Proneness on the role of negative prices, there is a negative influence on the role price on Coupon Proneness on the role of negative prices, there is a positive influence on the role price on Price quality schema on the role of negative prices and there is a positive influence on the role price against Prestige sensitivity.
\end{abstract}

Kata kunci : Value Consciousness, Price Consciousness, Coupon Proneness, Sale Proneness, Price Mavenism, Price Quality Schema dan Prestige Sensitivity 


\section{Journal Competency of Business \\ 2019 Vol 3. No II}

\section{LATAR BELAKANG MASALAH}

Dalam persaingan memperebutkan konsumen, sebuah perusahaan dapat memahami konsumen dengan lebih baik dibanding pesaingnya. Pemahaman terhadap perilaku konsumen (Customer Behaviour) memegang peranan penting di dalam hal ini. Untuk itu perlu dilakukan upaya secara sistematis untuk menggali data dan informasi mengenai perilaku konsumen, baik perilaku yang tampak, maupun yang tidak tampak.

Perilaku pembelian dari konsumen merupakan hal yang sangat penting untuk dipelajari dan diperhatikan oleh para peritel saat ini. Perilaku pembelian (buying behavior) adalah proses pengambilan keputusan dan tindakan seseorang dalam pembelian dan penggunaan produk. Perilaku pembelian konsumen bisa dilihat dari keinginan untuk membeli produk, intensitas dalam pembelian produk, dan tindakan merekomendasikan pembelian produk kepada orang lain. Oleh sebab itu, peritel harus mampu memunculkan strategi-strategi yang mampu membuat konsumen melakukan pembelian ulang terhadap merek produk kebutuhan seharihari tersebut.

Begitu juga halnya dengan Indo Grosir, dimana Indo Grosir memiliki strategi yang mampu membuat konsumen melakukan pembelian ulang untuk kebutuhan sehari-hari mereka. Indo Grosir sesuai dengan namanya memberikan harga yang murah dalam setiap penjualan produknya, sehingga banyak yang menjadikan Indo Grosir sebagai tempat memenuhi kebutuhan hidup mereka seharihari. Indo Grosir yang memiliki tempat yang sangat besar dan mewah menyebabkan konsumen betah untuk berlama-lama dalam berbelanja. Kualitas produk yang ditawarkan juga beragam, dari yang berkualitas biasa hingga yang berkualitas paling baik. Harga yang rendah tersebut menyebabkan Indogrosir memiliki pelanggan yang banyak dari berbagai kalangan, sehingga perilaku pembelian dalam berbagai segi pembelian dapat ditentukan melalui produk yang di beli.

Salah satu aspek yang mempengaruhi perilaku konsumen adalah harga. Persepsi terhadap harga merupakan fenomena yang menarik untuk diteliti (provocative issue). Pergeseran-pergeseran paradigma, dinamika gaya hidup, serta 


\section{Journal Competency of Business \\ 2019 Vol 3. No II}

berbagai perubahan lingkungan lain telah memberikan dampak pada bagaiman konsumen memandang harga produk/jasa yang akan dikonsumsinya.

Erickson dan Johansson (1985) membuat model peran ganda harga dalam suatu penelitian dan menemukan bahwa persepsi tingkat harga mempunyai efek negatif langsung terhadap intensitas pembelian, dan efek positif tidak langsung terhadap intensitas pembelian melalui persepsi produk-kualitas. Dengan demikian interpretasi dan persepsi harga dapat dibedakan menurut efek positif (menyukai harga tinggi) dan efek negatif (menyukai harga rendah).

Berdasarkan penelitian yang dilakukan oleh Lightenstein et.al (1993), telah mendefinisikan tujuh konsepsi yang berhubungan dengan interpretasi dan persepsi harga (Price-Related Construct), serta lima reaksi atau perilaku konsumen dalam menanggapi harga dan promosi harga.

Tujuh konsepsi yang berhubungan dengan persespi harga tersebut lima diantaranya mempengaruhi peran negatif probabilitas pembelian dengan semakin rendah harga, dan disebut sebagai "peran negatif". Kelima fakta yang memiliki peran negatif tersebut, yaitu Price Consciousness, Value Consciousness, Coupon Proneness, sale Proneness, dan Price Mavenism. Dua dari tujuh konsepsi sisanya memiliki pengaruh terhadap probabilitas pembelian secara positif dengan semakin tingginya harga, dan disebut sebagai "peran positif". Sedangkan dua fakta diantaranya yang memiliki peran postif tersebut, yaitu Price scheme dan prestige sensitivity.

\section{KAJIAN PUSTAKA}

\section{a. Negative Role of Price}

Untuk mengidentifikasi beberapa cara yang mungkin mengikuti dan reaksi terhadap harga dan promosi harga, dalam penelitian ini digunakan sebuah tinjauan yang luas dari harga dan literature promosi penjualan. Lima konstruk konsisten dengan persepsi harga yang berada dalam negative role dan dua konstruk konsisten dengan persepsi harga yang berada dalam positive role. Konstruk-konstruk tersebut dapat dijelaskan sebagai berikut: 


\section{Journal Competency of Business \\ 2019 Vol 3. No II}

\section{1) Value Consciousness.}

Persepsi harga merupakan isyarat bagi beberap konsumen agar dapat mengenali karakteristik dengan memperhatikan rasio dari kualitas yang diterima terhadap harga yang dibayarkan dalam sebuah transaksi. Beberapa peneliti menjelaskan mengenai konsep "nilai" dalam teori yang sesuai dengan perspektif penelitian ini (misalnya Lichtenstein, Netemeyer, dan Burton 1990; Tellis \& Gaeth 1990; Thaler 1985; Zeithaml 1988). Oleh karena itu, value consciousness merupakan refleksi dari sebuah kesadaran terhadap harga yang dibayarkan sesuai dengan kualitas yang didapat.

2) Price consciousness.

Persepsi harga merupakan isyarat bagi beberapa konsumen untuk dapat mengenali refleksi price consciousness. Melalui istilah "price consciousness" yang telah digunakan oleh beberapa peneliti yang berbeda yang berkenaan mengenai variasi dari hubungan harga dengan kognisi (Zeithaml, dalam Lichtenstein, et.al., 1993). Dalam penelitian ini digunakan pendekatan yang sangat sempit untuk mendapatkan derajat perhatian konsumen secara eklusif terhadap harga yang murah. Definisi ini juga konsisten dengan beberapa peneliti (seperti Erickson \& Johansson 1985; Lichtenstein, Bloch, dan Black 1988; Monroe \& Petroshius 1981; Tellis \& Gaeth 1990)

3) Coupon proneness.

Persepsi harga sebagai isyarat dalam negative role dapat dihubungkan dengan bentuk (form) dari isyarat harga yang ada. Konsisten dengan perspektif yang ada, dimana beberapa peneliti berpendapat bahwa pengurangan harga dalam bentuk kupon dapat meningkatkan respon konsumen melebihi dari harga yang murah tanpa kupon (Lichtenstein, Netemeyer, and Burton, dalam Lichtenstein, Ridgway, dan Netemeyer, 1993).

4) Sale proneness.

Konsep pemikirannya sangat mirip dengan coupon proneness pada beberapa konsumen, peningkatan sensitivitas terhadap harga dalam negative role berhubungan dengan harga dalam bentuk penjualan, yang berupa diskon yang berasal dari harga penjualan secara regular (contoh harga penjualan regular $\$ 1.99$, harga diskon menjadi \$1.29). Iklan dari sebuah harga diskon yang 


\section{Journal Competency of Business \\ 2019 Vol 3. No II}

menyertai referensi harga (iklan harga komparatif) ditemukan bahwa peningkatan persepsi dari nilai melebihi derajat dari harga yang tidak didiskon (Monroe and Chapman, dalam Lichtenstein, et.al., 1993). Hal ini dikarenakan evaluasi harga dari akibat oleh harga yang didiskon.

5) Price mavenism.

Merupakan persepsi dari harga dalam negative role yang berhubungan dengan hasrat untuk memberi informasi mengenai harga kepada orang lain. Feick and Price (dalam Lichtenstein, et.al., 1993) mendukung dugaan ini, dimana konsumen dapat menjadi membuat "market mavens" dikarenakan hasrat konsumen untuk memberikan informasi mengenai pasar kepada orang lain. Hal ini dikarenakan secara umum informasi harga di pasar menonjol. Hal ini merupakan sebuah sensistivitas harga dalam negative role bagi beberapa konsumen yang direfleksikan melalui sebuah hasrat untuk menjadi "price mavens", sebagai sumber dari informasi harga yang murah bagi orang lain. Penelitian ini menggunakan definisi market mavens dari Lichtenstein, et.al., (1993) yang dimodifikasi dari pengertian market mavens Feick and Price (1987), yaitu tingkat dimana seseorang dapat menjadi sumber informasi harga untuk berbagai macam produk dan toko yang memberikan harga murah, memulai diskusi dengan konsumen, dan respon terhadap permintaan dari konsumen mengenai informasi harga.

Tujuh konsepsi yang berhubungan dengan persespi harga tersebut lima diantaranya mempengaruhi peran negatif probabilitas pembelian dengan semakin rendah harga, dan disebut sebagai "peran negatif". Kelima fakta yang memiliki peran negatif tersebut, yaitu Price Consciousness, Value Consciousness, Coupon Proneness, sale Proneness, dan Price Mavenism. Dua dari tujuh konsepsi sisanya memiliki pengaruh terhadap probabilitas pembelian secara positif dengan semakin tingginya harga, dan disebut sebagai "peran positif". Sedangkan dua fakta diantaranya yang memiliki peran postif tersebut, yaitu Price Scheme dan prestige Sensitivity.

Untuk variabel negative role price dapat dijelaskan sebagai berikut; Kesadaran nilai fisik produk (value conciousness) merupakan kesadaran konsumen akan pentingnya nilai produk yang diukur dari harga terhadap 


\section{Journal Competency of Business \\ 2019 Vol 3. No II}

fisiknya. Semakin rendah harga dianggap semakin tinggi nilai produk tersebut, sehingga lebih dipilih. Dalam hal ini variabel tersebut untuk mengukur sejauh mana konsumen mempertimbangkan nilai fisik produk, yang ditunjukkan oleh persepsi konsumen terhadap pentingnya pertimbangan nilai fisik produk. Price mavenism merupakan persepsi mengenai harga yang berhubungan dengan keinginan untuk memberitahukan mengenai harga disuatu pasar kepada orang lain, informasi yang diberikan berhubungan dengan harga yang rendah, dimana tempat memberikan harga yang rendah. Kesadaran harga (price conciousness) merupakan kesadaran konsumen akan pentingnya harga yang rendah dalam membeli produk. Semakin rendah harga, semakin dilpilih sesuai dengan preferensi terhadap harga rendah. Potongan harga (sale proneness) berkaitan dengan persepsi konsumen mengenai produk-produk yang ditawarkan dalam potongan harga. Potongan harga dianggap menguntungkan karena harganya lebih rendah dari harga semestinya, sejalan dengan hal ini maka harga rendah lebih dipilih. Coupon proneness merupakan isyarat mengenai harga dalam peran negatif berhubungan dengan bentuk isyarat harga yang ada. Beberapa peneliti berpendapat bahwa potongan harga dalam bentuk kupon dapat menyebabkan peningkatan respon konsumen selama hasilnya lebih rendah dari harga non kupon.

Berdasarkan hasil pembahasan tersebut dikemukakan hipotesis penelitian sebagai berikut:

H1: Terdapat pengaruh negative role price terhadap Value Consciousness

$\mathrm{H} 2$ : Terdapat pengaruh negative role price terhadap Price Mavenism

H3: Terdapat pengaruh negative role price terhadap Price Consciousness

H4: Terdapat pengaruh negative role price terhadap sale Proneness

H5: Terdapat pengaruh negative role price terhadap Coupon Proneness

\section{b. Positive Role of Price}

1) Price-quality schema.

Untuk beberapa konsumen, harga disyaratkan sebagai sebuah positive role, karena tingkat dari isyarat harga adalah berhubungan positif dengan tingkat kualitas produk (Erickson and Johansson, dalam Lichtenstein, et.al., 1993). Untuk tingkat harga yang dirasakan oleh konsumen. Konsumen memandang 


\section{Journal Competency of Business \\ 2019 Vol 3. No II}

harga yang mahal lebih disukai karena persepsi peningkatan kualitas produk akan membuat biaya produksi menjadi mahal (Lichtenstein, Bloch, dan Black, dalam Lichtenstein, et.al., 1993). Pada faktanya, dikarenakan konsumen merasa harga pada kondisi ini harus mempersiapkan dana yang besar untuk membayar produk dengan harga yang mahal, perilaku berbelanja dipersiapkan sebagai "price seeking" (Tellis and Gaeth dalam Lichtenstein, et.al., 1993). Definisi dari price-quality schema adalah sebagai kepercayaan secara umum mengenai kategori produk terhadap tingkat isyarat harga yang berhubungan positif dengan tingkat kualitas produk.

2) Prestige sensitivity.

Sama dengan persepsi dari isyarat harga yang didasari pada sinyal pembeli kualitas produk yang berpesepsi bahwa isyarat harga menjadi kesimpulan akhir dari apa yang disebut dengan sinyal terhadap orang lain mengenai pembelian. Sebagai contoh, untuk derajat dari konsumen yang membeli anggur dengan harga mahal bukan dikarenakan persepsi kualitasnya, tetapi dikarenakan persepsi dari orang lain mengenai apa yang mereka beli (persepsi mengenai orang kaya), persepsi positif dari isyarat harga didasarkan pada persepsi orang lain dalam sebuah lingkungan social. Selanjutnya didefinisikan sebagai sensitivitas "gengsi", sebagai persepsi yang diinginkan dari isyarat harga bedasarkan perasaan terkemuka dan status sosial yang selalu membeli dengan harga yang lebih tinggi daripada orang lain.

Untuk variabel positive role price dapat dijelaskan sebagai berikut; Harga-kualitas (price-quality scheme) merupakan hubungan harga dan kualitas yang berkaitan dengan anggapan bahwa harga produk sebanding dengan kualitasnya, semakin tinggi harga maka akan semakin dipilih, karena dianggap mencerminkan kualitas yang semakin bagus (Lightenstein et.al, 1993). Hargaprestise (prestige sensitivity) berkaitan dengan anggapan produk yang dibeli menunjukkan status atau gengsi. Semakin tinggi harga semakin dipilih, karena dianggap semakin memberikan prestise.

Berdasarkan hasil pembahasan tersebut dikemukakan hipotesis penelitian sebagai berikut:

H6: Terdapat pengaruh positive role price terhadap price quality schema 


\section{Journal Competency of Business \\ 2019 Vol 3. No II}

H7: Terdapat pengaruh positive role price terhadap Prestige sensitivity.

H8: Terdapat hubungan yang signifikan antara negative role price dengan positive role price

\section{METODE PENELITIAN}

\section{Populasi dan Sampel}

Populasi dalam penelitian ini adalah konsumen yang sedang melakukan pembelian atau mereka yang pernah melakukan pembelian di Indo Grosir Jalan Magelang Yogyakarta. Sedangkan Metode pengambilan sampel dalam penelitian ini adalah convenience sampling yakni sampel di ambil berdasarkan ketersediaan responden dan kemudahan untuk memperoleh datanya. Dalam convenience sampling peneliti memiliki kebebasan untuk memilih siapa saja yang mereka temui (Cooper, 1997). Setiap orang yang berada di Indogrosir dan telah mengalami pengalaman dengan produk dan pelayanan Indogrosir tersebut memiliki kesempatan yang sama untuk dipilih sebagai anggota sampel. Jumlah sampel yang ditentukan dalam penelitian ini sebanyak 250 orang, hal ini telah memenuhi asumsi penggunaan SEM dan dikarenakan keterbatasan waktu dan biaya. Sampel dalam penelitian ini adalah konsumen yang sedang melakukan pembelian atau mereka yang pernah melakukan pembelian di Indogrosir jalan Magelang Yogyakarta.

\section{HASIL ANALISIS DATA}

\section{Model diagram jalur}

Pada pengukuran model diagram jalur dilakukan dengan menyusun model struktural dengan menghubungkan antar konstruk laten baik endogen maupun eksogen dan menyusun measurement model dengan menghubungkan konstruk laten endogen atau eksogen dengan variabel indikator atau manifest. Penggambaran diagram jalur dan besarnya koefisien path, dapat ditunjukkan dalam gambar berikut : 


\section{Journal Competency of Business \\ 2019 Vol 3. No II}

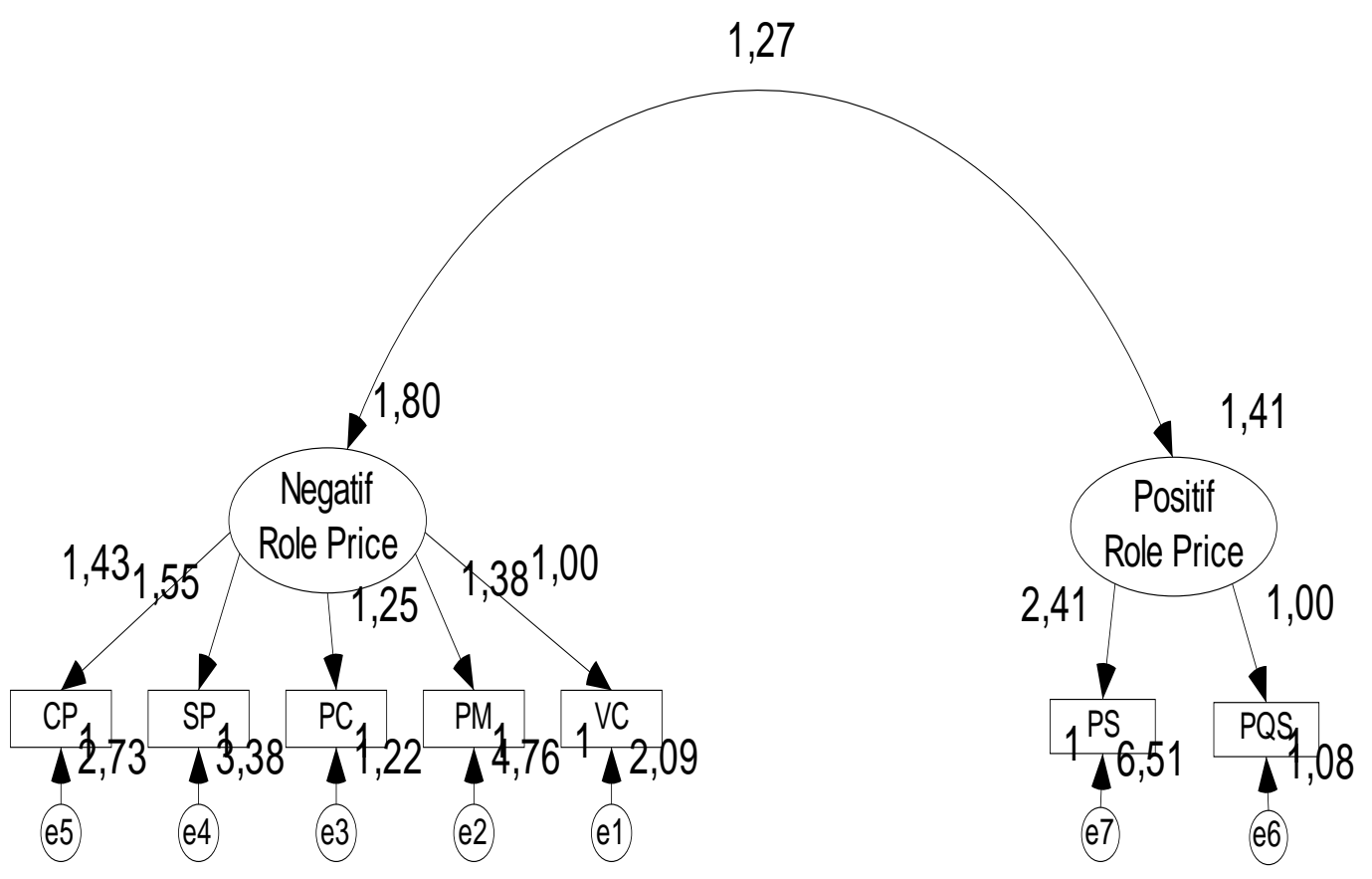

Gambar 1. Hasil Uji Model Hipotesis

\section{Evaluasi Asumsi Normalitas}

Sebelum melakukan pengujian model struktural dengan pendekatan structural equation modeling, asumsi yang harus diuji yaitu Uji Normalitas Sebaran. Nilai statistik untuk menguji normalitas disebut $t$ value (Critical Ratio atau C.R pada output AMOS 7.0) dari ukuran skewness dan kurtosis sebaran data. Bila nilai C.R lebih besar dari nilai kritis maka dapat diduga bahwa distribusi data tidak normal. Nilai kritis dapat ditentukan berdasarkan nilai sebaran antara -2.58 sampai dengan 2.58. Hasil uji normalitas data disajikan pada tabel berikut.

Tabel 1. Hasil Uji Normalitas Sebaran Data

\begin{tabular}{|l|rrrrrr|}
\hline Variable & $\min$ & $\max$ & skew & c.r. & kurtosis & c.r. \\
\hline PS & 18,000 & 40,000 &, 031 &, 199 &,- 040 &,- 129 \\
PQS & 9,000 & 15,000 &, 231 & 1,489 &,- 253 &,- 818 \\
\hline
\end{tabular}




\section{Journal Competency of Business \\ 2019 Vol 3. No II}

\begin{tabular}{|l|rrrrrr|}
\hline Variable & $\min$ & $\max$ & skew & c.r. & kurtosis & c.r. \\
\hline CP & 14,000 & 25,000 &, 281 & 1,811 &,- 359 & $-1,159$ \\
SP & 11,000 & 25,000 &, 147 &, 948 &, 430 & 1,388 \\
PC & 11,000 & 20,000 &, 633 & 2,084 &, 101 &, 324 \\
PM & 17,000 & 30,000 &, 481 & 2,106 &,- 191 &,- 618 \\
VC & 10,000 & 20,000 &,- 088 &,- 567 &, 706 & 2,279 \\
Multivariate & & & & & 2,643 & 1,791 \\
\hline
\end{tabular}

Sumber: Hasil Olah Data

Berdasarkan Tabel tersebut, terlihat bahwa secara keseluruhan nilai C.R sebaran skewness dan kurtosis pada seluruh indikator lebih kecil (dalam harga mutlak) dari 2,58 yang berarti distribusi normal. Dengan demikian, asumsi normalitas multivariate dapat dipenuhi dan data yang ada dapat digunakan dalam penelitian ini yang berasal dari data primer berdasarkan jawaban 250 responden, sehingga diperoleh data yang mengikuti distribusi normal multivariate.

\section{Evaluasi Kriteria Goodness of Fit}

Evaluasi terhadap model multifaktor dari pengukuran di atas menghasilkan indeks-indeks goodness of fit sebagaimana disajikan pada tabel berikut:

Tabel 2. Hasil Goodness of Fit Model Pengukuran

\begin{tabular}{|l|c|c|c|}
\hline \multicolumn{1}{|c|}{ Index } & $\begin{array}{c}\text { Cut off } \\
\text { Value }\end{array}$ & Hasil & $\begin{array}{c}\text { Evaluasi } \\
\text { Model }\end{array}$ \\
\hline Chi-Square & & 11,902 & \\
\hline Probabilitas & $\geq 0,05$ &, 108 & Baik \\
\hline CMIN/DF & $\leq 2,00$ & 0,223 & Baik \\
\hline GFI & $\geq 0,90$ & 0,913 & Baik \\
\hline AGFI & $\geq 0,90$ & 0,902 & Baik \\
\hline
\end{tabular}




\section{Journal Competency of Business \\ 2019 Vol 3. No II}

\begin{tabular}{|l|c|c|c|}
\hline TLI & $\geq 0,95$ & 0,952 & Baik \\
\hline CFI & $\geq 0,95$ & 0,967 & Baik \\
\hline RMSEA & $\leq 0,08$ & 0,010 & Baik \\
\hline
\end{tabular}

Sumber: Hasil Olah Data

Indeks-indeks goodness of fit model pengukuran (measurement model) pada Tabel di atas menunjukkan hasil yang baik, sehingga model yang ada telah memberikan estimasi model yang fit dan dapat menjadi model struktural penuh pada model awal tersebut.

\section{Hasil Pengujian Hipotesis dan Pembahasan}

Hipotesis yang merepresentasikan pengaruh suatu konstruk terhadap konstruk lain diuji dengan memeriksa apakah koefisien path (standardized estimate) yang menghubungkan kedua konstruk tersebut signifikan pada taraf signifikansi $\alpha=0,05$. Rangkuman hasil pengujian hipotesis bisa dilihat pada tabel berikut ini.

Tabel 3. Rangkuman Hasil Uji Hipotesis

\begin{tabular}{|c|l|c|c|c|}
\hline Hipotesis & \multicolumn{1}{|c|}{ Path Hubungan } & $\begin{array}{c}\text { Standardized } \\
\text { Estimated }\end{array}$ & C.R & Keterangan \\
\hline H1 & $\begin{array}{l}\text { Negative role price } \rightarrow \\
\text { Positive Role Price }\end{array}$ & 1,275 & 6,806 & Terbukti \\
\hline H2 & $\begin{array}{l}\text { Negative role price } \rightarrow \\
\text { Value Consciousness }\end{array}$ & 1,032 & 8,423 & Terbukti \\
\hline H3 & Negative role price $\rightarrow$ & 1,381 & 9,120 & Terbukti \\
\hline \multirow{2}{*}{\begin{tabular}{l} 
Price Mavenism \\
\hline
\end{tabular}}
\end{tabular}




\section{Journal Competency of Business \\ 2019 Vol 3. No II}

\begin{tabular}{|c|c|c|c|c|}
\hline $\mathrm{H} 4$ & $\begin{array}{l}\text { Negative role price } \rightarrow \\
\text { Price Consciousness }\end{array}$ & 1,252 & 11,309 & Terbukti \\
\hline H5 & $\begin{array}{l}\text { Negative role price } \rightarrow \\
\text { Sale Proneness }\end{array}$ & 1,547 & 10,361 & Terbukti \\
\hline H6 & $\begin{array}{l}\text { Negative role price } \rightarrow \\
\text { Coupon Proneness }\end{array}$ & 1,427 & 10,461 & Terbukti \\
\hline $\mathrm{H} 7$ & $\begin{array}{l}\text { Positif Role Price } \rightarrow \\
\text { Price Quality Schema }\end{array}$ & 1,365 & 7,512 & Terbukti \\
\hline H8 & $\begin{array}{l}\text { Positif Role Price } \rightarrow \\
\text { Prestige Sensitivity }\end{array}$ & 2,406 & 9,407 & Terbukti \\
\hline
\end{tabular}

* signifikan pada level 0,05.

Berdasarkan hasil estimasi model pada Tabel tersebut, interpretasi masing-masing pengujian hipotesis di atas dapat diuraikan sebagai berikut:

a. Pengujian hipotesis pertama

Hasil estimasi pengaruh negative role price terhadap positif role price diperoleh koefisien path (standardized estimate) sebesar 1,275. Uji signifikansi koefisien ini diperoleh nilai C.R sebesar 6,806. Karena nilai C.R lebih besar dari 2,0 maka terima hipotesis pada taraf signifikan 5\%, yang berarti ada pengaruh dari variabel negative role price terhadap positif role price. Dengan demikian hipotesis 1 yang menyatakan bahwa variabel negative role price berpengaruh signifikan terhadap positif role price pada peranan harga negatif terbukti. Hal ini berarti makin tingginya negative role price menjadikan tingginya positif role price.

b. Pengujian hipotesis kedua

Hasil estimasi pengaruh negative role price terhadap Value Consciousness diperoleh koefisien path sebesar 1,032 dan nilai C.R sebesar 8,423. Karena nilai C.R lebih besar dari 2,0 maka terima hipotesis pada taraf signifikan 5\%, yang berarti ada pengaruh negative role price terhadap Value Consciousness. Dengan demikian hipotesis 2 yang menyatakan terdapat 


\section{Journal Competency of Business \\ 2019 Vol 3. No II}

pengaruh negative role price terhadap Value Consciousness pada peranan harga negatif terbukti.

c. Pengujian hipotesis ketiga

Hasil estimasi pengaruh negative role price terhadap Price Mavenism diperoleh koefisien path sebesar 1,381 dan nilai C.R sebesar 8,423. Karena nilai C.R lebih besar dari 2,0 maka terima hipotesis pada taraf signifikan 5\%, yang berarti ada pengaruh negative role price terhadap Price Mavenism. Dengan demikian hipotesis 3 yang menyatakan bahwa terdapat pengaruh negative role price terhadap Price Mavenism pada peranan harga negatif terbukti.

d. Pengujian hipotesis keempat

diperoleh koefisien path sebesar 1,252 dan nilai C.R sebesar 11,309. Karena nilai C.R lebih besar dari 2,0 maka terima hipotesis pada taraf signifikan 5\%, yang berarti ada pengaruh negative role price terhadap Price Consciousness. Dengan demikian hipotesis 4 yang menyatakan bahwa terdapat pengaruh negative role price terhadap Price Consciousness pada peranan harga negatif terbukti.

e. Pengujian hipotesis kelima

Hasil estimasi pengaruh negative role price terhadap Sale Proneness diperoleh koefisien path sebesar 1,547 dan nilai C.R sebesar 10,361. Karena nilai C.R lebih besar dari 2,0 maka terima hipotesis pada taraf signifikan 5\%, yang berarti ada pengaruh negative role price terhadap Sale Proneness. Dengan demikian hipotesis 5 yang menyatakan bahwa terdapat pengaruh negative role price terhadap Sale Proneness pada peranan harga negatif terbukti.

f. Pengujian hipotesis keenam

Hasil estimasi pengaruh negative role price terhadap Coupon Proneness diperoleh koefisien path sebesar 1,427 dan nilai C.R sebesar 10,461. Karena nilai C.R lebih besar dari 2,0 maka terima hipotesis pada taraf signifikan $5 \%$, yang berarti ada pengaruh negative role price terhadap 


\section{Journal Competency of Business \\ 2019 Vol 3. No II}

Coupon Proneness. Dengan demikian hipotesis 6 yang menyatakan bahwa terdapat pengaruh negative role price terhadap Coupon Proneness pada peranan harga negatif terbukti.

g. Pengujian hipotesis ketujuh

Hasil estimasi pengaruh positif role price terhadap Price quality schema diperoleh koefisien path sebesar 1,365 dan nilai C.R sebesar 7,512. Karena nilai C.R lebih besar dari 2,0 maka terima hipotesis pada taraf signifikan $5 \%$, yang berarti ada pengaruh positif role price terhadap Price quality schema. Dengan demikian hipotesis 7 yang menyatakan bahwa terdapat pengaruh positif role price terhadap Price quality schema pada peranan harga negatif terbukti.

h. Pengujian hipotesis kedelapan

Hasil estimasi pengaruh positif role price terhadap Prestige sensitivity diperoleh koefisien path sebesar 2,406 dan nilai C.R sebesar 9,407. Karena nilai C.R lebih besar dari 2,0 maka terima hipotesis pada taraf signifikan 5\%, yang berarti ada pengaruh positif role price terhadap Prestige sensitivity. Dengan demikian hipotesis 6 yang menyatakan bahwa terdapat pengaruh positif role price terhadap Prestige sensitivity pada peranan harga negatif terbukti. 


\section{Journal Competency of Business \\ 2019 Vol 3. No II}

\section{KESIMPULAN DAN SARAN}

Berdasarkan hasil analisis dan pembahasan tentang hubungan persepsi konsumen mengenai peranan harga negatif dan promosi harga (Price Consciousness, Value Consciousness, Coupon Proneness, sale Proneness, dan Price Mavenism) dengan peranan harga positif (price quality schema dan Prestige sensitivity) maka dapat ditarik kesimpulan bahwa terdapat pengaruh negative role price terhadap Value Consciousness, Konsumen Indogrosir menganggap pentingnya nilai produk yang dijual Indogrosir yang diukur dari harga terhadap fisiknya. Semakin rendah harga dianggap semakin tinggi nilai produk tersebut, sehingga lebih dipilih oleh konsumen Indogrosir, terdapat pengaruh negative role price terhadap Price Mavenism, Persepsi konsumen Indogrosir mengenai harga yang berhubungan dengan keinginan konsumen Indogrosir untuk memberitahukan mengenai harga di Indogrosir kepada orang lain, informasi yang diberikan berhubungan dengan harga yang rendah, dimana pada saat Indogrosir memberikan harga yang rendah, terdapat pengaruh negative role price terhadap Price Consciousness, Kesadaran konsumen Indogrosir akan pentingnya harga yang rendah dalam membeli produk. Semakin rendah harga, semakin dilpilih sesuai dengan preferensi terhadap harga rendah yang ditawarkan Indogrosir, terdapat pengaruh negative role price terhadap Sale Proneness, Potongan harga (sale proneness) berkaitan dengan persepsi konsumen Indogrosir mengenai produk-produk yang ditawarkan dalam potongan harga. Potongan harga dianggap menguntungkan karena harganya lebih rendah dari harga semestinya, sejalan dengan hal ini maka harga rendah lebih dipilih konsumen Indogrosir, terdapat pengaruh negative role price terhadap Coupon Pronenes, Isyarat mengenai harga dalam peran negatif berhubungan dengan bentuk isyarat harga yang ada pada Indogrosir. Potongan harga dalam bentuk kupon dapat menyebabkan peningkatan respon konsumen Indogrosir selama hasilnya lebih rendah dari harga non kupon yang ada pada Hypermarket Indogrosir.

Terdapat pengaruh positive role price terhadap price quality schema, Hubungan harga dan kualitas yang berkaitan dengan anggapan bahwa harga produk sebanding dengan kualitasnya yang ditawarkan Indogrosir, semakin tinggi harga maka akan semakin dipilih konsumen, karena dianggap mencerminkan kualitas Indogrosir yang semakin bagus, terdapat pengaruh positive role price terhadap Prestige sensitivity, 


\section{Journal Competency of Business \\ 2019 Vol 3. No II}

Anggapan produk yang dibeli konsumen Indogrosir menunjukkan status atau gengsi bagi mereka. Semakin tinggi harga semakin dipilih, karena dianggap semakin memberikan prestise bagi konsumen Indogrosir serta terdapat pengaruh positive role price terhadap negative role price, Persepsi tingkat harga mempunyai efek negatif langsung terhadap intensitas pembelian konsumen Indogrosir, dan efek positif tidak langsung terhadap intensitas pembelian konsumen Indogrosir melalui persepsi produkkualitas yang ditawarkan pada Hypermarket Indogrosir. 


\section{Journal Competency of Business \\ 2019 Vol 3. No II}

\section{DAFTAR PUSTAKA}

Budiadi, Nang Among. (2009). Analisis Pengaruh Persepsi Harga terhadap Perilaku Pembelian Produk Kebutuhan Sehari-hari. Jurnal Bisnis dan Kewirausahaan. Vol. 2 No.3 April 2009.

Cooper, Donald R. 1997. Metode Penelitian Bisnis. Jakarta: Erlangga

Dharmesta, Basu Swastha, 2003, Azas-azas Marketing, Yogyakarta : Liberty

Dickson P. R. and A. G. Sawyer. 1985. The Price Knowledge and Search of Supermarket Shoppers. Journal of Marketing, Vol. 54 (July), 42-53

Erickson, Gary M. dan Johansson, Johny K. 1985. The Role of Price in Multi Attribute Product Evaluations, the Journal of Consumer Research. Vol. 12. Hal. 195-199

Feick, Lawrence F. and Linda L. Price 1987, 'The Market Maven: A Diffuser of Marketplace Information, Journal of Marketing, 51 (January), 83-97.

Ferdinand, A., 2002, Structural Equation Modeling dalam Penelitian Manajemen, Edisi ke 2, BP UNDIP, Semarang

Ghozali dan Fuad. 2005. Structural equation modeling Teori Konsep \& Aplikasi Dengan Program Lisrel 8.54. Semarang: Badan Penerbit UNDIP

Hair et al., 1998, Multivariate Data Analysis, Fifth Edition, Prentice Hall, Upper Saddle River : New Jersy.

Hoyle, R. 1995, Structural Equation Modelling: Concepts, Issues and Applications, Sage, Thousand Oaks, CA

Lichtenstein, D. R., \& Burton, S. 1989. The relationship between perceived and objective price-quality. Journal of Marketing Research, 26, 429-443

Lichtenstein, Donald, Nancy M. Ridgeway, and Richard G. Netemeyer, (1993) "Price Perceptions and Consumer Shopping Behavior: A Field Study, Journal of Marketing Research, vol. 30 (May), 234-245.

Lichtenstein, Donald, Richard G. Netemeyer and Scot Burton (1990), "Distinguishing Coupon Proneness from Price Consciousness: An Acquisition-Transaction Utility Perspective, Journal of Marketing, vol. 54 (July), 54-67.

Malhotra, Naresh K. 2005. Riset Pemasaran. (Pendekatan Terapan). Terjemahan Soleh Rusyadi M. Jakarta PT. Indeks Kelompok Gramedia

Monroe, Kent B. and Susan Petroshius. 1981. "Buyers' Perception of Price: An Update of the Findings", Glenview, IL: Scott, Foresman and Company, 43-55.

Peterson, R. A., \& Wilson, W. R. 1985. Perceived risk and price reliance schema as price-perceived quality mediators. Lexington, MA: D.C. Heath and Company.

Siagian, Dergibson dan Sugiarto, Metode statistika Untuk Bisnis dan Ekonomi, penerbit. PT. Gramedia Pustaka Utama

Stanton, William J. 1998. Prinsip Pemasaran. terjemahan Y.Lamarto, Erlangga Jakarta

Supardi. 2005. Metode Penelitian Ekonomi dan Bisnis. Yogyakarta: UII Press

Tellis, Gerard J. and Gary J. Gaeth (1990), "Best Value, Price-Seeking, and Price Aversion: The Impact of Information and Learning on Consumer Choices, Journal of Marketing, vol. 54 (April), 34-45

Thaler, R. H. 1990. 'Saving, fungibility and mental accounts', Journal of Economic Perspectives, Vol.4, 193-205.

Zeithaml, V.A. 1988. Consumer perceptions of price, quality, and value: A means-end model and synthesis of evidence. Journal of Marketing, 52(3), 2 - 22. 
Journal Competency of Business

2019 Vol 3. No II 